\title{
PHILOSOPHY OF LANGUAGE: PRAGMATIC PRESUPPOSITION IN MOTIVATIONAL SPEECH WITHIN DISCOURSE AND ITS RELEVANCE OF MOTIVATION IN TEACHING LEARNING PROCESS TO REACH GOALS
}

\author{
Nurul Ulfa Nistiti \\ Universitas Negeri Surabaya \\ e-mail:nurul.20030@mhs.unesa.ac.id
}

\begin{abstract}
This research was taken from online media in the form of a speech on a YouTube channel called the English Speeches Channel featuring an inspiring woman named Muniba Mazari Baloch. She is a Pakistani artist, model, activist, motivational speaker, singer, social reformer, and television host. Her motivational speech is titled we all are Perfectly Imperfect. This research accompaniment three research questions by analyzing the types of presuppositions contained in Muniba Mazari's speech and determining the type of presupposition in his speech that comes up with the confession discourse function, then knowing how far her confessions influences her audiencess through what he delivers. The research method used in this research is descriptive qualitative by analyzing several utterances in her speech, through two approaches of theory pragmatic presupposition and confessional discourse analysis. The results showed that Muniba Mazari used all types of pragmatic presuppositions (Existential, Factive, Non-Factive, Lexical, Structural, and Counterfactual). Through this type of presupposition, Muniba Mazari also brings out the function of confessional discourse. The function of confessional discourse contained in her speech is a therapeutic, didactic, and interrogatory function. During the research, researchers found the main threat from the combination of these two theories is the strength of Motivational Assertion. The main threat that became the main idea as the direction of Muniba Mazari's speech in motivating her audiences. Then, this main thread also asserts how powerful Muniba Mazari's speech was. In this context, the results bring about optimism, achievable objectives, passion, and confidence. Finally, Muniba Mazari's speech entitled We Are Perfectly Imperfect which contains many moral messages can be said to be a motivational speech. It can be manifested in learning-teaching process. The result of combining these two theories produces the main thread that can be applied by several teachers in motivating their students in the learning-teaching process.
\end{abstract}

Keywords: Types of Presupposition, Confessional Discourse, Speech, Motivational Speech, Teaching-learning process. 


\section{INTRODUCTION}

Communication is an important part that cannot be separated from human life as a social being. In practical terms, communication is understanding as to the process of delivering information or messages by a communicator to the communicant through convinced means with goals and impacts (McBath \& Jeffrey, 1978). In general, communication can be done verbally and can be understood by both parties concerned. One way of verbal communication that can be done by the community, particularly through speech (Iversen \& Norpoth, 2011). In the form of communication through this speech, the communicator process of creating and sharing ideas, information, views, facts, feelings, among their audiences to achieve a common understanding. As a form of spoken language, giving a speech emphasizes the expression of ideas and reasoning by using spoken language, which is supported by non-linguistic aspects which are facial expressions, gestures, sight contact, etc. (Kubrick \& Clarke, 2001).

Speech is carried out in the form of speech or words so that it is two-way (Kormos, 2014). Speech is one type of public speaking activity, such as presentations, deliberations, speeches, or campaigns. So there is a speaker as a conveyor orally, and there is a listener or audiences as a receiver. The word speech itself has a meaning that we can see from various points of view. In a speech, the speaker will speak in front of the crowd to convey an issue to achieve certain goals. The speaker also intends to convince the listener with hope then the listener will be awakened by the speaker's conscience (Sapir, 1921).

During the speaker's speech, the speaker must be able to attract their audiencess' attention by delivering a speech well so that the listener can comfortably ingest what the speaker says. Therefore, the speaker must know and understand the content of the speech to be delivered. In this way, the speaker can persuade the audiences to do what speaker has to say. There are several types of speech, one of which is motivational speech (Telg, 2011). A motivational speech is a speech that tells about someone whose goal is to provide inspiration or motivation (Telg, 2011). This speech can also be interpreted as a speech that has a message to be conveyed to the public. For example, live happily with all the flaws you have. A speech that tells the life story of a character who can become a role model for readers. Speakers usually share stories in various forms such as experiences, places, stories, and certain people that will make the listener feel the urge to act.

Speakers can identify speech as information that is assumed to be accurate, and it will be associated with the knowledge they have. Through the speech, the speaker conveys their information to the listener will be the initial assumption that the listener will get. Sometimes in a communication process like this, the speaker inserts the meaning or implied message in it.

As we know, sometimes the speaker does the presumption explicitly or implicitly because some of the speeches delivered by the speaker are known only by the speaker, and the listener can suppose what the speaker said by their respective perspectives(Colomina-Almiñana, 2018).

It means, from the information above. It is confirmed, that there are several possible linguistic approaches used by speakers in achieving some goals. So, in this speech activity, some of the speaker's utterances can be analyzed through a linguistic theory in the form of theoretical studies. Furthermore, this study of linguistic theory will be used to find out more about the meaning contained in the utterances in the speaker's speech(van der Sandt, 2015). One of the theoretical studies used in this research is called the Pragmatic Presupposition. Presupposition is something that is 
assumed by the speaker as an event before producing a speech (Yule, 1996). Presuppositions (presuppositions) are correlated with the use of word forms, phrases, sentences, and structures (Yule, 1996). Presupposition (presupposition) comes from the English word "pre-suppose" which means the listener presupposes first. Before the speaker or writer says something that already has preconceived notions about the interlocutor or the thing being discussed (Nirit Kadmon, 2001). Presupposition is something which the speaker assumes as the case before pronouncing or the presumptive speaker(van der Sandt, 2015). Presuppositions can be defined informally as conclusions or propositions whose truth is taken for granted in a sentence(Caffi, 2006). Presuppositions can be informally defined as inferences or propositions whose truth is taken for granted in a sentence. Presupposition is classified into six types, consist of existential presuppositions, factice presuppositions, lexical presuppositions, structural presuppositions, non-active presuppositions, and counter-factual presuppositions (Yule, 1996).

This study not only carried the theory of presupposition pragmatics but also through a discourse approach. The discourse approach used to analyze is called confessional discourse(Leeuwen, 2008). This discourse refers more to the confessions used by women in telling their life stories. The confession discourse is that speakers focus on the structure of language and how the speaker influences the audiences's perspective (Fairclough, 2013). In a sense, who will become the subject and object of the story and who will determine the how the structure of text and meaning threaded in the text overall.

The discourse theory of this recognition is also supported by (Mandziuk, 2001) which means that one of the speakers, who is a woman wants to convey her story, opinions, and views, and suggestions that are displayed using several implied meanings based on her life experience, to give a positive influence and a sense of enthusiasm. There are three types of Confessional Discourse Function which are confession as therapeutic, confession as didactic, and confession as interrogatory (Mandziuk, 2001). Confessional Discourse also includes self-development development to explain how confessor becomes role models according to their personal experiences (Ariyanti \& Nistiti, 2019). The confessor shares his experience with the aim that his audiences can learn something from it (Ariyanti \& Nistiti, 2019). The confessor also sometimes asks several questions about his perspective on better influence on their audiences (Ariyanti \& Nistiti, 2019).

Through these two theories, it will be obtained facts about how this woman speaker acknowledged something she experienced and what the meaning of some of the confessions she expressed, and what was the purpose. In this context, it also usually contains elements of presupposition in the form of several implied statements.

In this study the writer would like to focus on analyze about presupposition in Muniba Mazari Baloch's Speech because the title speech is "We Are Perfectly Imperfect". She is a Pakistani artist and activist. This speech was published on the English Speeches in YouTube channel on 6th July 2018, it discusses her story of her life that was so beautiful before the accident that it made him feel sad to sit in the wheelchair. Automatically, data for this research earns to be analyzed in-depth based on Muniba Mazari as a woman representation that shows how she stands as a woman but persists in living her life and shares motivational stories to many people. From that case, some of the words she said could examine through the discourse as a motivational purpose. The purpose of this study is to explain the types of presuppositions and discourses of confession in aasserting the functions in Muniba Mazari's speech and 
determining. Then, revealing how the type of assumption can be supported the function of confession discourse and knowing how far her confessions influences her audiences.

As the explanation above, the researcher also tries to reveal the results of Muniba Mazari's speech analysis to be applied in giving motivation by the teacher in the teaching-learning process.Therefore, the use of language is the reality of communication interactions that take place in teaching and learning activities to reach the goals. Teachers in this exchange activity must be able to communicate well, create a fun and meaningful learning atmosphere for students, and make them active students. In realizing the enthusiasm for student learning, the teacher must be able to motivate the class well, equipped with language actions that can improve student enthusiasm for learning.

\section{METHOD}

This study used the descriptive qualitative method. The approach used in this study is qualitative. It is because the data obtained is in the form of speech data or written words(Creswell, 1991). Meanwhile, this method was chosen because it is the focus of the study, particularly describing the results of Muniba Mazari's speech text analysis as an motivational speech is titled we all are Perfectly Imperfect (Stephen D. Lapan, Marylynn T. Quartaroli, 2012). She is a Pakistani activist, anchor artist, model, singer and motivational speaker. She became the National Ambassador for UN Women Pakistan after being shortlisted in the 100 Motivational Women of 2015 by $\mathrm{BBC}$. The researcher serves as instruments that act as data collectors, data analyzers, and reporters of research results. In collecting data, the authors searched for data sources on one of the Youtube channels which are English Speeches. The data for RQ1 and RQ 2 obtained is in the form of words, phrases, or sentences that required an explanation which is classified based on the aspects studied, then For RQ3 data is taken from sample of some of the audiences's comments in English Speeches Channel (Sarah J. Tracy, 2013). These aspects are data that have several intended meanings that can be recognized clearly. This study asserts the results of the three research questions, which are:

1. What features of presupposition in Muniba Mazari's speech can construct?

2. In what ways does the presupposition come up with the confession in Muniba Mazari's speech?

3. How its relevance in motivation in the teaching-learning process to reach goals?

\section{RESULT AND DISCUSSION}

In analyzing the data, the researcher uses two theories, there are the main theory and the supporting theory. The main theory used is the type of presupposition in pragmatics by George Yule 1996 . The first theory will explain what types of presuppositions are used by Muniba Mazari as an object. Then, this main theory also is supported by a second theory which is a confessional discourse based on the research of Mandziuk 2010. This review of the main theories and supporting theories will be reflected by the author. The aim is to prove how powerfull the results of the analysis from the combined study of these two theories are. 


\section{Type of presupposition in Therapeutic Function of Muniba Mazari's Speech.}

Table 1. Existential Presupposition in Therapeutic Function

\begin{tabular}{|c|c|c|}
\hline \multicolumn{3}{|c|}{ Presupposition Sentences } \\
\hline \multicolumn{2}{|c|}{ Well, I always start my talk with a disclaimer } \\
\hline Presupposition Type & Confessional Discourse & Asserting its function \\
\hline Existential & Therapeutic function & $\begin{array}{c}\text { expresses her self- } \\
\text { realization }\end{array}$ \\
\hline
\end{tabular}

"Well, I always start my talk with a disclaimer. And that disclaimer is that I have never claimed to be a motivational speaker. Yes, I do speak. But I feel more like a storyteller, because wherever I go, I share a story with everyone".

In the context of the existential presupposition of "Well, I always start my talk with a disclaimer " Muniba Mazari tries to start her speech with a little intermezzo, she does not mean to claim her speech as a motivational speech. However, she wants to tell her story to the audiences, hoping that later those who listen to her speech can take the moral message and can feel better than before. In her existential presupposition, which refers to a therapeutic function, she also expresses her selfrealization to her audiences through events that make her strong that She got fired from all the necessary things that need to live every day without any discomfort. She shares her stories wherever he goes and makes people realize that everyone can achieve what she did. In her powerful and inspiring speech, Muniba shares coming to terms with her new purpose while being confined to a bed for two years.

Table 2. Factive Presupposition in Therapeutic Function

\begin{tabular}{|c|c|c|}
\hline \multicolumn{3}{|c|}{ Presupposition Sentences } \\
\hline \multicolumn{3}{|c|}{ I call myself differently abled } \\
\hline Presupposition Type & Confessional Discourse & Asserting its function \\
\hline Existential & Therapeutic function & $\begin{array}{c}\text { Becoming the role } \\
\text { model }\end{array}$ \\
\hline
\end{tabular}

"They call it adversity; I call it opportunity. They call it weakness, I call it strength. They call me disabled, I call myself differently abled. They see my disability. They see my disability. I see my ability".

Muniba Mazari shared, "I call myself differently abled" this utterance shows her existential presupposition. She emphasizes "Myself" as a form of identity. Indeed, she tells her true-condition based on what she has gone through. In this case, Muniba has learned that accidents can happen. Accidents will happen. An accident can somehow damage her body but also change her soul and land her in a wheelchair. She considers 
that her current condition is a blessing in disguise because it can transform her into the best version of herself.

Muniba Mazari uses existential presupposition to support her confession, as a therapeutic function. She becomes a role model for her audiencess based on the truth. Her main message that she never thought that being in a wheelchair all the time would damage her pride. Therefore, she also gives a statement "differently-abled" that a person with a disability like herself, of course, could still develop herself well. But it doesn't matter what flaws she has to rise to be a stronger and more confident self.

Table 3. Non-Factive Presupposition in Therapeutic Function

\begin{tabular}{|c|c|c|}
\hline \multicolumn{3}{|c|}{ Presupposition Sentences } \\
\hline \multicolumn{2}{|c|}{ Failure is an option, should be an option. But giving up is not. } \\
\hline Presupposition Type & Confessional Discourse & Asserting its function \\
\hline Non-Factive & Therapeutic function & $\begin{array}{c}\text { Giving notify about } \\
\text { some values }\end{array}$ \\
\hline
\end{tabular}

"Failure is an option, should be an option. But giving up is not. Never. A failure is an option, must be an option. But giving up is not. Never".

It is indicated her lexical presupposition. In this presupposition, Muniba tries to deliver about keep forward and don't give up to their audiencess. According to Muniba, failure should be an option "Because after failing, we can get up, and that is what makes us move forward". We must enjoy every breath we take, enjoy our life. Muniba's accident was like a big calamity in Muniba's life. With her experience of fighting against adversity, Muniba decided to get up. She tried to survive more often appear in public. Muniba's step for more active social activities. Muniba campaigned for the rights of women and children. People say that failure shouldn't be an option.

Muniba uses her lexical presupposition to support her therapeutic function. She can give a notify to her audiencess. So they can act to don't give up must be accompanied by a high sense of enthusiasm. To have an attitude that never gives up, will make someone easy to rise from adversity. As evidenced by Muniba's achievements within her limitations. She started painting and hosted TV shows. Muniba is also the Ambassador at UN Women to Pakistan.

Table 4. Counterfactual Presupposition in Therapeutic Function

\begin{tabular}{|c|c|c|}
\hline \multicolumn{3}{|c|}{ Presupposition Sentences } \\
\hline \multicolumn{2}{|c|}{ If I will smile I can make people smile, that keeps me going } \\
\hline Presupposition Type & Confessional Discourse & Asserting its function \\
\hline Conterfactual & Therapeutic function & $\begin{array}{c}\text { Stating her self } \\
\text { realization }\end{array}$ \\
\hline
\end{tabular}




\section{"And I smile all day because I know that if I will smile I can make people smile, that keeps me going".}

The sentence "If I will smile I can make people smile, that keeps me going." is Muniba's counterfactual presupposition that means the power behind the smile. This presupposition contains the assumption that Muniba tries to always smile at others. She considers that a smile is a sign that we are open to others, even to strangers. If other people smile at us, we will smile automatically too.

In this presupposition, there is also a therapeutic function. Muniba states her selfrealization to convey advice to her audiences through what she does. She is stated by her statement that smiling is an easy way to make ourselves and others around us happy. When we feel happy, of course, it will be easy to smile. That way we can understand how important smiling is for ourselves and others. Besides, we can interpret smiles through pearls of wisdom about smiling. Through pearls of wisdom about smiling, we come to understand and appreciate the meaning of a smile.

\section{Type of Presupposition in Didactic Function of Muniba Mazari's Speech.}

Table 5. Factive Presupposition in Didactic Function

\begin{tabular}{|c|c|c|}
\hline \multicolumn{3}{|c|}{ Presupposition Sentences } \\
\hline \multicolumn{2}{|c|}{ So I always try to use the positive words in my life wherever I go. } \\
\hline Presupposition Type & Confessional Discourse & Asserting its function \\
\hline Factive & Didactic function & Sharing positive value \\
\hline
\end{tabular}

"I believe in the power of words. Many people speak before they think. But I know the value of words. Words can make you, break you, they can heal your soul, they can damage you forever. So I always try to use the positive words in my life wherever I go".

This utterances "I always try to use the positive words in my life wherever I go" is her factive presupposition based on the fact about her journey of recovery and discovery. The most inspiring thing about Muniba's talk, and how she navigates her life today with the power of words, is the lesson that despite society's view of how we should confirm and exist, we can still create and be exactly what we want to be. Then, Muniba has achieved this. It is triggered by her didactic function, she said that to achieve what he dreams of in life, focus on positive things. It will influence the spirit to act. It can be hard to feel discouraged if you can't maintain positive thoughts because some efforts can achieve life goals. Like, when "Muniba's life experiences and lessons that regardless of people's views on how we should strengthen and exist, we can still create and become what we want. She has achieved this. Muniba also emphasized that people will feel happy if they always have positive thoughts. Positive thoughts will give birth to enthusiasm in living this life. High hopes will be owned by someone who can maintain the spirit that is in them. 
Table 6. Non-Factive Presupposition in Didactic Function

\begin{tabular}{|c|c|c|}
\hline \multicolumn{3}{|c|}{ Presupposition Sentences } \\
\hline $\begin{array}{c}\text { People think that they will not be accepted by the people because we and } \\
\text { the world of perfect people are imperfects }\end{array}$ \\
\hline Presupposition Type & Confessional Discourse & Asserting its function \\
\hline Non-Factive & Didactic function & Sharing positive value \\
\hline
\end{tabular}

\section{"The lack of acceptance. People think that they will not be accepted by the people because we and the world of perfect people are imperfects".}

In this presupposition "People think that they will not be accepted by the people because we and the world of perfect people are imperfects." Muniba emphasizes the lack of acceptance. By following what was experienced by Muniba after the accident he experienced. She has to be in a wheelchair and several other disadvantages. Yet she felt that it was not time to be sad. She tried to fight it all. Muniba's experience led him to people who also need the same strength, to face severe trials, just like after Muniba's accident. To that end, Muniba decided to tell him about what it was like to be in a wheelchair. During this period, Muniba decides to live a life for himself. She no longer wants to be perfect for others, including her family, for her husband. She also takes this moment to try to be perfect, only for herself.

Muniba uses non-factive presupposition in her didactic function to emphasize what she experienced so that her audiences can retrieve messages from her. She states how people who spend their lives in a wheelchair think that they not be accepted in society because they feel they are not perfect in a world of ideal people. His story motivates the world a lot. Muniba also implicitly invites her audiences to stop comparing themselves with others or to always measure oneself based on wealth is identical to humiliating ourselves or considering ourselves as no more meaningful than others. Based on all people born unique according to their versions.

Table 7. Lexical Presupposition in Didactic Function

\begin{tabular}{|c|c|c|}
\hline \multicolumn{3}{|c|}{ Presupposition Sentences } \\
\hline \multicolumn{2}{|c|}{ when you accept yourself the way you are, the world recognizes you } \\
\hline Presupposition Type & Confessional Discourse & Asserting its function \\
\hline Lexical & Didactic function & Maintaining a confident \\
\hline
\end{tabular}

"So, when you accept yourself the way you are, the world recognizes you. It all starts from within".

In Muniba's utterances "When you accept yourself as you are, the world recognizes you" which is indicated lexical presupposition. It also emphasizes self- 
acceptance. Muniba's experience led her to people who also need the same strength, facing severe trials, such as after Muniba's accident. To that end, Muniba decided to tell her about what it was like to be in a wheelchair. In this way, Muniba could try to fight his fear. She wrote down one by one of her fears and immediately overcame them and accepted her current state.

Therefore, through her lexical presupposition, which also contains a teaching lesson as a didactic function. In this function, Muniba explained. If a person has a spirit of self-acceptance, they do not need to feel perfect to feel valuable in the eyes of others. It is enough to look at the positive side that is in her. When they face unpleasant realities, they often feel a need for the presence of the love of others. While we don't get love from other people and not someone is there when we feel down. Even though the most important thing is love from ourselves so that we can accept ourselves.

Table 8. Lexical Presupposition in Didactic Function

\begin{tabular}{|c|c|c|}
\hline \multicolumn{3}{|c|}{ Presupposition Sentences } \\
\hline God has a bigger plan and one day you will say that oh my God that is \\
why God has chosen me \\
\hline Presupposition Type & Confessional Discourse & Asserting its function \\
\hline Lexical & Didactic function & $\begin{array}{c}\text { Encouraging powerful } \\
\text { beliefs }\end{array}$ \\
\hline
\end{tabular}

"This too shall pass. God has a bigger plan and one day you will say that oh my God that is why God has chosen me."

Lexical Presupposition in her utterances "God has bigger plans and one day you will say that oh my God that is why God has chosen me" Muniba realized that God might put him in the middle of trouble and test her patience. In the end, God gave her the victory. Losing hope always brings her closer to the line of failure. However, she still has faith in herself and most importantly, she always has faith in God who always stands by her in your good times and bad.

In this context, Muniba expressed to her audiences to inspire them. In her lexical presupposition, she comes up with the didactic function to give a little warning to his audiencess, so they can take lessons from her story Life will not be complete until and unless it does not have the ingredients to be an inspiration to others. Muniba has gone through a phase of life where he can't even think of a single reason to survive. But she stood up, fought off, and proved what real women's power is all about. Today she is a true inspiration character for the all people of not only Pakistan but the entire world. 
Table 9. Counterfactual Presupposition in Didactic Function

\begin{tabular}{|c|c|c|}
\hline \multicolumn{3}{|c|}{ Presupposition Sentences } \\
\hline \multicolumn{3}{|c|}{ This life is a test and a trial } \\
\hline Presupposition Type & Confessional Discourse & Asserting its function \\
\hline Counterfactual & Didactic function & Finding its lesson \\
\hline
\end{tabular}

"This life is a test and a trial. And tests or trials are never supposed to be easy. So when you're expecting ease from life and life gives you lemons, then you make the lemonade and then do not blame life for that, because you were expecting ease from a trial. Life is a test and a trial" expresses with the statement "So when you expect the convenience of life".

In her early statement, Muniba has the assumption that if life is not always easy, sometimes there are some unexpected things. As she experienced, at the age of 21, Muniba lost her leg in an accident. Therefore, it made her married life completely destroyed. It made her think for a moment about why she had to come back to life. But she stood up and found the motivation to live a happy life. She got rid of all her fears and learned how to fight her weaknesses and stay strong.

In Muniba's counterfactual presupposition, she states to her audiences. So, her audiencess could understand the purpose of the statement. Thus, in the context of her presupposition Muniba brings up from didactic functions, which explains that in 12 years, Muniba learned that life is very difficult to predict. Life is full of a series of unwanted and unexpected events. How in the blink of an eye everything changed. How in the blink of an eye her life changed. And, how in a moment my eyes changed. She learned that, with all these changes, she is becoming a better person every day. Muniba started painting professionally and participated in many modeling activities. And now, she became the first woman in a wheelchair to become a news anchor on Pakistan National TV.

Table 10. Factive Type in Didactic Presupposition

\begin{tabular}{|c|c|c|}
\hline \multicolumn{3}{|c|}{ Presupposition Sentences } \\
\hline \multicolumn{3}{|c|}{ Real happiness lies in gratitude. } \\
So be grateful and be alive and live every moment. \\
\hline Presupposition Type & Confessional Discourse & Asserting its function \\
\hline Factive & Didactic function & Giving a warning \\
\hline
\end{tabular}

"The real happiness doesn't lie in money or success or fame. I have this all and I never wanted this. Real happiness lies in gratitude. So be grateful and be alive and live every moment" 
The real happiness doesn't lie in money or success or fame this sentence explains the fact that Muniba is still grateful for what has happened to her at this time. Muniba's experience has led her to people who also need the same strength, to face severe trials, just like after Muniba's accident. To that end, Muniba decided to tell him about what it was like to be in a wheelchair.

In this intended meaning, Muniba wants to confess her audiencess to remain grateful for what they already have. This type of presupposition also supports her didactic function to achieve Muniba's goals. Muniba's goal is to give a little warning that whatever happens, we must be grateful and keep fighting without giving up. For some people, it is difficult to forget their past they have gone through. Muniba, despite her disability, used her artistic talents as an opportunity to be a source of inspiration for others. She sets the perfect example for all those who are in a similar state to her.

\section{Type of Presupposition in Integratory Function of Muniba Mazari's Speech.}

Table 11. Structural Presupposition in Integratory Function

\begin{tabular}{|c|c|c|}
\hline \multicolumn{3}{|c|}{ Presupposition Sentences } \\
\hline \multicolumn{2}{|c|}{ Why am I even alive? What's the point of living? } \\
\hline Presupposition Type & Confessional Discourse & Asserting its function \\
\hline Structural & Integratory & $\begin{array}{c}\text { Giving the hope by } \\
\text { some questions }\end{array}$ \\
\hline
\end{tabular}

"I started to question my existence: Why am I even alive? What's the point of living? I cannot walk, I cannot paint, fine. I cannot be a mother and we have this thing in our head being women that we are incomplete without having children. I am going to be an incomplete woman for the rest of my life. What's the point?".

Muniba's utterances through this sentences "Why am I even alive? What's the point of living?" indicated that she uses structural presupposition. In her structural presupposition she raises a question to herself about her tragic car accident. There are three bitter facts that she had to accept while lying in the hospital for so long. The first day when her doctor asked that She wants to be an artist, instead of becoming a housewife. Then, her doctor has bad news that she can not paint againMuniba took a heavy breath, tried to accept her fate, and she said that she was okay. Due to the severity of the spinal cord injury, the doctor concluded that she would no longer walk. Yes, right. That was all she could say. Not only that, due to her injury to the bones, ribs, and almost all bones. The doctor said that Muniba would not give birth to another child. Here, she despaired because she does not feel like she could be a true woman. The thought of the life she would lead in the future was terrifying. With this presupposition, she arises a question through integratory function "have you ever wondered why she is still alive today? Why has she died yet? Why does she have to survive until now, while many people have gone before her? What exactly is the existence of your existence in this world?. In such a heart-breaking state, She lost her zeal to live and questioned the existence of her life, why it is me? why am I still alive? 
why is she still given life in such dire conditions? she was so desperate. Then, what is the point of living? If you are not able to walk. She can not do whatever she wants. She is not being able to provide a child for her husband, insurance that hit her instincts. However, She realized that there was no point in blaming fate. Shutting up in sadness will surely make it worse because she tried to think positively to stay alive. The spirit is given by her mother " this too shall pass. God has a bigger plan for you. I don't know what, but he knows. " Those magic words seemed to transmit enthusiasm and hope. Make her then write one by one the fear in her life. She convinced herself that it came from one thing, but only fear. Muniba will face them one by one.

In her integratory function, she is interpreted through the questions to her audiences "Have you ever thought that your life is useless anymore? Or have you ever asked about your existence?". It has a meaning as a messenger for her audiences who feel to give up easily and cannot find meaning in life. So, she tried to include an implicit question so that her audiences would understand the moral message that she was implied in it. In particular, about how hard life is and no matter how strong the wind blows. It's not that we are all useless, it is just that we haven't realized how important we are in life.

Table 12. Structural Presupposition in Integratory Function

\begin{tabular}{|c|c|c|}
\hline \multicolumn{3}{|c|}{ Presupposition Sentences } \\
\hline \multicolumn{2}{|c|}{ You know what makes you perfect? When you make someone smile. } \\
\hline Presupposition Type & Confessional Discourse & Asserting its function \\
\hline structural & Intregatory function & $\begin{array}{c}\text { Conveying self- } \\
\text { assured by rising the } \\
\end{array}$ \\
question \\
\hline
\end{tabular}

"You know what makes you perfect? When you make someone smile. You know what makes you perfect? When you try to do something good for the people around you. You know what makes you perfect? When you feel someone's pain."

Muniba tried to ask her audiences a question, with the phrase "You know what makes you perfect? When it makes someone smile". In this case Muniba uses structural presupposition by rising a question before then she explains with other statement. Her question has a meaning "Give them a defeating answer with a charming smile, but never expose your sorrows and weaknesses to the world. Muniba also states that if you are willing to accept yourself with all your strengths and weaknesses completely, then nothing can stop you from rising to become a stronger and more confident self. From this, Muniba tries to always spread positive things and happiness to those around her.

Muniba uses structural presupposition in her confession to support her message. In this utterance, she raises the interrogatory function through rises questions to explain her implicit meaning about how to make other people happy. Smiling can not only have a positive effect on your emotional level. She also emphasizes, smiling, you 
can also make other people happy. With one smile we can transmit a positive aura to others.

\section{The Strength of Motivational Assertion.}

In English Spechess, Muniba Mazari uses speech in his communication strategy. In her speech entitled "Perfectly Imperfect," she shared the story of her life. She was paralyzed from the hip down after surviving a tragic car accident. After a few years, she tried to get up and come back to the public to share positive vibes with everyone. This section will be divided into two sections based on the research results. The first section is the finding of the correlation between two theories which are pragmatic presupposition, and confessional discourse. Then, the second part is to answer the last research question. The data taken from the third research question is a sample of some of the audiences's comments. This audiences comment will support whether it is related to the results of the analysis from two previous research questions. The results of the combination of these two theories are displayed in the chart below:

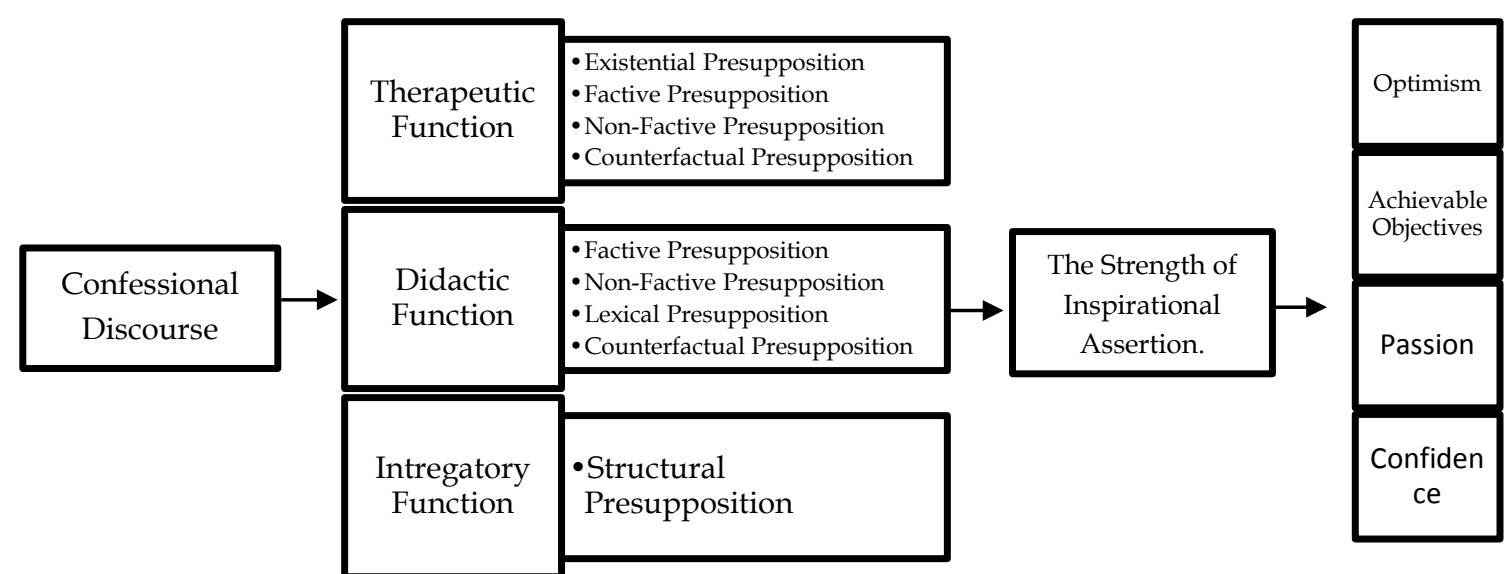

Previously, researchers analyzed two questions in this study. The first question answers the types of conditions used by Muniba Mazari in his speech. After the researcher analyzed several utterances in Muniba Mazari's speech, It was found that she used all types of presuppositions: existential, lexical, factive, non-factive, structural, and counterfactual. The second research question, in what way the presupposition emerges with this confession Muniba Mazari's speech. It turns out the various types of presuppositions that have been found, It also contains functions of confessional discourse. So, these two theories can be combined and finally lead to a common thread as new findings in this research. According to Mandziukk (2013), the confessional discourse function in Muniba Mazari's speech has three functions which are therapeutic, didactic, and intregatory functions. The first function, in the Therapeutic function, contains four types of presuppositions: Existential presupposition, Factive Presupposition, Non-Factive Presupposition, and Counterfactual presupposition. The second function, in the Didactic function, contains four types of presupposition: Factive presupposition, Non-factive presupposition, Structural presupposition, and Counterfactual presupposition. Then, the last function, the Intregatory function has one type of presupposition which is Structural presupposition. 
Throughout the researcher's journey, the researcher found the main idea of the results of asserting two theories which is the Strength of Motivational Assertion. This shows that Muniba Mazari's speech is powerful and inspiring. Muniba shares coming to terms with her new purpose while being confined to a bed for two years after the car accident. From this main idea, four common threads are brought about, which are optimism, achievable objectives, passion, and confidence.

\section{Its Relevance in Motivation in the Teaching-Learning Process to Reach Goals.}

The result from the combination between confessional and pragmatics in Arel Moodie's Speech can supported motivation in the teaching-learning process to reach goals. Motivation can determine whether to achieve goals. The greater the motivation, the greater the willingness to survive. Students don't any want to give and survive. On the other hand, some people, especially students with low motivation, seem indifferent, give up easily, and lack attention. Not interested in learning will cause many experiences. Learning difficulties. People think this will affect academic achievement. This is similar to states: "The learning motivation that students have in any learning activity is very important to improve academic achievement. Students learn in certain subjects ".

\section{Reflected Optimism.}

A big word that means that Muniba Mazari's utterances have a mental impact on a positive idea or activity for his audiences. Some who are inspired to see bigger and better possibilities. Though this evidence of data, through analysis of the types of presuppositions and how Muniba tells her story through her confessions, her audiences feels inspired.

In teaching-learning process activities, teachers must be able to foster a sense of enthusiasm for learning by increasing learning motivation. Motivation to learn is a driving force or impetus that makes someone interested in learning so that they will learn continuously. Low motivation can cause low success in learning so that it will lower student achievement.

\section{Reflected Achievable Objectives.}

From Muniba's speech, the audiences found something valuable. It is this valuable thing that is interpreted as achievable Objectives. This achievable objective is an motivational value.

Generally, students will show their interest in learning to teachers who care about them. The teacher must build positive relationships with students. teachers can tell them your positive life story. And, teachers must build positive relationships with students. It's easy, the teacher can tell them your positive life story.

\section{Reflected Passion.}

Muniba's speech succeeded in arousing her audiences's enthusiasm to do something he liked or considered to do. Her audiencess indicated that they must have high morale according to their passion. Teachers may bring personal passion into the classroom because this will strengthen it to create stronger lessons. It will also allow students to see how their unique skills are prepared based on their passions. It can be important, useful, and useful for their future. Almost every personal passion can be incorporated into the learning process in the classroom. It means that not every 
personal passion can be included in classroom learning. Therefore we have to explore, try, improve, and adapt to learning needs.

\section{Reflected Confidence.}

In her speech, Muniva also shared many positives encouraging words. Therefore the audiences give the urge to act on their beliefs. If this is connected with motivation goals in the teaching-learning process, Confidence is one of the keys to success. A student who does not have self-confidence will hinder the development of intellectual achievement, skills, and independence and make the student unable to socialize. These students lack the courage to actualize themselves in a social environment. Self-distrust makes a person angry with himself and results in disruption of learning achievement. Most of the students who feel like failures with their achievements find it difficult to develop self-confidence. Fear of challenging tasks, fear of failure, and accustomed to taking on tasks that have no challenges.

These actions can increase self-confidence in someone, in this case, students. Self-confidence is one of the assets students need to achieve their success. If students have confidence, they will continue to be motivated to move forward and not be afraid to face challenges. Sufficient self-confidence will also lead them to life. From RQ3's answer, this is why Muniba Mazari's speech can be assert to be an motivational speech. Muniba's motivational speech has achieved her goal. The goal is how Muniba indirectly uses the type of presupposition type to achieve her confession with her audiences. Not only that, but the result of combining these two theories produces the main thread that can be applied by several teachers in motivating their students in the learning-teaching process.

\section{CONCLUSION}

After the researcher analyzed the research in the speech of a Pakistani activist Muniba Mazari entitled "we are perfectly imperfect". Researchers found that Muniba used all types of presuppositions: existential, lexical, factive, non-factive, structural, and counterfactual. All of these types are found in several statements presented as data in this study. Then, the next research question is how this type of presupposition come up with Muniba's confession that is explained through confessional function. As a result, confessional discourse and the types of presuppositions used by researchers can be combined. The confessional discourse raised by Muniba has three functions: therapeutic, didactic, and integratory.

After conducting the research, the researcher obtained sixteen data found in this study. Then, these two theories can be combined and interconnected. The first function, in the Therapeutic function, contains four types of presuppositions: Existential presupposition, Factive Presupposition, Non-Factive Presupposition, and Counterfactual presupposition. The second function, in the Didactic function, contains four types of presupposition: Factive presupposition, Non-factive presupposition, Structural presupposition, and Counterfactual presupposition. Then, the last function, the Intregatory function has one type of presupposition which is Structural presupposition. From this case, the researcher concluded that between the types of presuppositions that can come up into confessional discourse the function.

During the research, researchers found the main threat from the combination of these two theories is the strength of Motivational Assertion. The main threat that became the main idea as the direction of Muniba Mazari's speech in motivating her audiences. Then, this main thread answers the formulation of the third problem about 
how powerful Muniba Mazari's speech was. In this context, the results bring about optimism, achievable objectives, passion, and confidence. This is supported by several audience's comments. So, this research can achieve the goals of Muniba Mazari in conveying messages related to motivational encouragement to her audiences. Finally, Muniba Mazari's speech entitled We Are Perfectly Imperfect which contains many moral messages can be said to be a motivational speech. It can be manifested in learning-teaching process. The result of combining these two theories produces the main thread that can be applied by several teachers in motivating their students in the learning-teaching process.

\section{REFERENCES}

Ariyanti, L., \& Nistiti, N. U. (2019). Presupposition in Feminist Speech. 380(SoSHEC), 161-165.

Caffi, C. (2006). Pragmatic Presupposition. Encyclopedia of Language $\mathcal{E}$ Linguistics, 1936, 17-25.

Colomina-Almiñana, J. J. (2018). Pragmatic presupposition and unarticulated constituents. Lingua, 206, 112-126.

Creswell, J. W. (1991). Reseacrh Design. In Muqarnas (Vol. 8). SAGE Publications.

Fairclough, N. (2013). Critical discourse analysis the critical study of language, second edition. In Critical Discourse Analysis The Critical Study of Language, Second Edition.

Iversen, G., \& Norpoth, H. (2011). Introduction commmunication studies. In Analysis of Variance. Routledge.

Kormos, J. (2014). Speech Production and Second Language Acquisition. In Speech Production and Second Language Acquisition.

Kubrick, S., \& Clarke, A. C. (2001). Speech and Language Processing: An Introduction to Natural Language Processing, Computational Linguistics and Speech Recognition. In SPEECH and LANGUAGE PROCESSING An Introduction to Natural Language Processing Computational Linguistics and Speech Recognition.

Leeuwen, T. Van. (2008). Discourse and Practice. Oxford University Press.

Mandziuk, R. M. (2001). Confessional discourse and modern desires: Power and please in True Story magazine. Critical Studies in Media 
Communication, 18(2), 174-193. https:/ / doi.org/10.1080/07393180128076

McBath, J. H., \& Jeffrey, R. C. (1978). Defining Speech Communication. Communication Education, 27(3), 181-188.

Nirit Kadmon. (2001). Formal Pragmatics: Semantics, Pragmatics, Presupposition, and Focus. Blackwell Publishers Inc.

Sapir, E. (1921). "Language: An Introduction to the Study of Speech (Lengua: una introducción para estudio discursivo) (Vol. 15, Issue 18). Cambridge Library Collection.

Sarah J. Tracy. (2013). Qualitative Research Methods: Collecting Evidence, Crafting Analysis, Communicating Impact. In Revija za sociologiju (Vol. 43, Issue 1). Blackwell Publishers Inc.

Stephen D. Lapan, Marylynn T. Quartaroli, F. J. R. (2012). Qualitative Reseacrh. Jossey-Bass.

Telg, R. (2011). Speech Writing and Types of Speeches 1. In University of florida (Issue August).

van der Sandt, R. A. (2015). Linguistic Presupposition. In International Encyclopedia of the Social \& Behavioral Sciences: Second Edition (Second Edi, Vol. 13). Elsevier.

Yule, G. (1996). Pragmatics. In Areal Features of the Anglophone World. Oxford University Press. https:/ / doi.org/10.4324/9781315760483-11 